\title{
Institutionalization of Muslim Women Leadership (Case Study of Majelis taklim in Makassar)
}

\author{
Nuvida RAF ${ }^{1}$, Sultan $^{2}$, Patta Hindi ${ }^{3}$, Musrayani Usman ${ }^{4}$ \\ \{upikraf@gmail.com¹, sultan_djibe69@gmail.com², pattahindi@gmail.com ${ }^{3}$, \\ yaniunhas@gmail.com ${ }^{4}$ \} \\ Department of Sociology, Universitas Hasanuddin, Jl. Perintis Kemerdekaan KM 10, Makassar, \\ Indonesia $^{1,2,4}$, Government Science of Study Programme, Muhammadiyah University, Jl. KH. Ahmad \\ Dahlan No. 10, Kendari, Southeast Sulawesi, Indonesia ${ }^{3}$
}

\begin{abstract}
Study on functions of Majelis taklim showed its new function as a medium of institutionalization of Muslim women leadership since this grass root organization fights to fulfill the requirement of Islamic preachers for its regular meetings. The process of institutionalization is started by accepting female preachers, and they are from secular educational background but they have already trained as the Islamic preachers through specific trainings on Islamic teachings to Islamic leadership. Generally, female preachers are the head of majelis taklim who plays significant roles in spreading Islamic teaching, organizing regular religious meetings, and managing the board of organization. By using the case study on 2 majelis taklim in Makassar, research results are the number of Muslim women elite increases promisingly, and at the same time institutionalization of Muslim women leadership runs. These conditions bring advantages to such political parties because new elite women are becoming the potent candidates of legislative member in terms of having bases of mass that lead to increasing number of ballots for party in moment of legislative election.
\end{abstract}

Keywords: Majelis taklim, Muslim women elite, institutionalization, Islamic leadership.

\section{Introduction}

Leadership is always associated to male dominant almost in every fields of life. However, in Indonesian religious lives, the phenomenon of Muslim women leadership emerges at the level of the grass root organizations such as majelis taklim, an organization for women and it is organized by women. The number of majelis taklim or small group of Muslim women increases day by day along with the development of sub districts in Indonesia. Specially in Makassar, majelis taklim is established almost in every mosques. Raf [1] [2] explained that increasing number of majelis taklim is a kind of religiousity phenomenon in Indonesia. The Ministry of Religous Affairs registered that in 2013 the number of majelis taklim reached 165.000 respectively. In terms of culture, it has been acknowledged that Islam has been an identity of Buginese and Makassarese [3]-[5]. Here, culture drives Muslim women in Makassar to practice Islamic teachings in daily life, and majelis taklim is one of sources to gain and enrich their religiousities.

Majelis taklim conducts several activities collectively such as reciting Qur'an, listening and learning Islamic teachings that are delivered by a male preacher, deepening understanding 
on Qur'anic ayah, and performing of salah as well as giving charity. Mostly, these activities emphasis on developing personal piety that leads to social piety [6] since the members of majelis taklim spread their understanding on Islamic teachings to their families and people at their surrounding. Asry [7] asserted that majelis taklim is supported by culture of Buginese and Makassarese. Since beginning majelis taklim runs in cultural arena [6], however todays majelis taklim is transforming into socio-political arena because of several factors; the lack of male preachers who are able to deliver Islamic teachings [8]. Meanwhile the demand of preacher increases along with many majelis taklim conduct regular meetings at the same time; the rising demand to female preachers who are able to answer certain problems related to Muslim women, create a convenient situation for Muslim women in exploring their feelings openly; and build the social trusting amongst members.

These changes lead to institutionalization of female preachers that have played a role model as the leader then becoming the elite of Muslim women. Mostly they are the head of or the boards of majelis taklim who become a representation of their each majelis taklim in the communication forum of all majelis taklim at the level of sub distric in Makassar such as Badan Kontak Majelis Taklim (BKMT). In this such forum, all representations of majelis taklim obtain several skills that related to dakwah (Islamic preaching) regularly. The output of these trainings is increasing number of female preachers who will organize and deliver Islamic teachings to the members of majelis taklim in Makassar.

\section{Research Method}

This research applied qualitative method that referring to the research aims; to gain a comprehensive description of institutionalization process in majelis taklim, and explore the how the members of majelis taklim in accepting and adapting to these changes. Creswell [9] emphasized that qualitative methods are able to explain the phenomena connection intensely since there is a wide sphere for reseachers to explore and deepen the issue precisely. Therefore a case study was implemented as Yin [10], Stake [11], Suyanto and Sutinah [12] asserted that this type of research leads to specific answers toward social phenomenon. Research conducted on December 2018 - January 2018 and covered two majelis taklim in sub districs of Tamalanrea and Biringkanaya, Makassar City, South Sulawesi. Collecting data used indepth interview as well as observation and participant observant during regular meeting of majelis taklim, and following every steps of activities. The subject of research is the head and several members of both majelis taklim because they played significant roles in organizing majelis taklim [13], [14] and experience some changes related to functions of majelis taklim.

\section{Result And Discussion}

Institusionalization is a process in which a new role emerges then accepting, and becoming a part of social reality. Berger and Luckmann [15][16] decribe that institutionalization is began from repeated externalization in which leads to a pattern. Here society starts to understand and experience it collectively. In general, leader and leadership are male jobs in public sphere. Meanwhile women are expected just doing domestic assignments. Therefore women elite is new phenomen and limited number, however this research showed an interesting occurance in organization majelis taklim. 
The term of majelis taklim is a special term in describing a small religious group in Indonesia [17] that conducts activities basically related to learning and reciting Qur'an. These are main functions of majelis taklim as the medium of non formal education and it has been acknowledged by The Ministry of Religious Affairs and Indonesian Muslim organizations such as Muhammadiyah and Nahdathul Ulama [18]. Nowadays various activities are provided by majelis taklim in order to empowering and fullfiling the members requirements such as sewing or cooking skill, organising money collection for charity, establishing group of Islamic music, and performing in a competion at the level of sub distric.

Since its increasing number, majelis taklim requires more Islamic preachers. Commonly its regular meeting, it called as ,pengajian“, is guided and teached by male Islamic preachers who have educational background from Islamic boarding school [19]. This such requirement is hard to be fullfilled since many majelis taklim conduct its ,pengajian " at the same time or day such as at afternoon weekend [20]. Meanwhile female Islamic prechers is limited, and they have already had their own majelis taklim This problem, in turns, drives the head or the board to solve it. In order to answer this challenge, Badan Kontak Majelis taklim (BKMT) as a forum of communication amongst majelis taklim in Indonesia, offers a training program such as training of Muballighoh [21], skill of public speaking, and management of organization for its members specially who are not graduated from Islamic schools. By following this kind of trainings from basic level to advance level, $B K M T$ enforces its members to be the Islamic preachers since they have already studied Islamic teachings and obtained suppervision instensely. This circumstance leads to firstly, emerging of female preachers. Day by day they play a significant role not only at their own majelis taklim but also at other majelis taklim. Public acknowledge their capabilities and trust them specially to discuss female issues such reproduction health in Islamic view comfortably than diccussing it with male preachers.

Secondly, socio-political condition has situated the female Islamic preachers as the new elite [8] [6] in political contestation since their influences to several majelis taklim which have significant number of members. Here female voters are the potent sources of vote for the legislative candidates. Both the female elites and members of majelis taklim are the target of political parties particularly in electoral moments [22]. In addition this phenomenon also is an effect of affirmative action of $30 \%$ quota for women representation [23].

Referring to these descriptions, institutionalization of women elite has already run at the grass root level of Indonesian society. It means that leadership is a kind of social action and it influences society indirectly. Since all human activities are the subject to habitualization [15], leadership of female preachers has repeated frequently and lead to a pattern that „pengajian“ is conducted and organized by the female preachers, at least guided by head of majelis taklim. Althought their abilities are questioned by the members, the female preachers bring different nuance in delivering Islamic teachings. Habitualization this kind of leadership means that the way and style of female leadership are in question but it is performed in the same manner and effort then leading to internalization. Different to male leadership in public sphere, the nuance of domestic sphere colours Muslim women leadership [24] which emphasizing on issues related to the roles of women at home such as nurturing, education of children to counceling for the victims of domestic violence [25]. Here society has defined the leadership of Muslim women as the challenge results of socio-political circumstances. As Berger and Luckmann elucidate that habitualization makes it unnecessary for each situation to be defined a new, step by step. A large variety of situations may be subsumed under its predefinitions [15] [16]. The female elite at level of majelis taklim, therefore, is an institutionalization of female leadership, and it is an extended function of majelis taklim in political system of Indonesia [8]. Jati [2] 
affirms this phenomen as the revival of Indonesian Muslims from the middle class who participate significantly not only in cultural sphere but also in political sphere.

Institutionalization of female elite also occurs because of firstly is family supporting in terms of division of labour in domestic sphere that has been understood clearly by every members of family. Althought women should play the doble works both in domestic and public spheres, they have already shown their abilities to cope these burdens. Secondly, culture and tradition of Buginess and Makassarese demand and create a piety circumstances to women [3], [4] since Islam has been their identities. Therefore their activities in majelis taklim are perceived as the perfomance of Islamic teaching and as the medium for increasing of their devoutness. Finally, the backing of majelis taklim members who have already trusted to these elites to make decison, represent, and deliver their voices in political system. These roles, in turns, are the signs of the era of women in Indonesia [19].

In sub districs of Tamalanrea and Biringkana, the number of majelis taklim increases a long with the number of development of new block of housing that is stayed by migrant family. These families bring their custum in perfomance of Islamic teaching as they practice at their origin homeland. By attending majelis taklim activities, they establish social relationship as well as Muslim sisterhood and solidarity in their neighborhood [20].

During electoral moments in Makassar, it has noted that several political parties try to approach the heads or the potent boards of majelis taklim and offer them to be the candidate of parliament members such as the Party of Justice and Properous (PKS) nominated a head of $B K M T$ Tamalanrea and Biringkanaya. Even thought she was unsuccessfull in gaining high number of votes, she has already contribute to place this party as the third winner in legislative election 2019. This means that female elite has already accepted by society even at the level of majelis taklim which spreads out in entire sub districs in Makassar. Institutionalization the female leader, of course, takes a longstanding implementation and accepting as a part of world life of Muslim women in Indonesia.

\section{Conclusion}

The occurrence of Muslim women elite from majelis taklim circle is institutionalized by society through habituation and internalization. Majelis taklim is a non formal forum of religious education mainly for women. It has involved a longstanding practices of female leadership in managing majelis taklim as an organization. The head or the board of majelis taklim experience the changes of its functions that extend from cultural activities to political activities since requirement of Islamic preachers has not fullfilled.

BKMT challenges this demand by providing a number of trainings that results in emerging the female preachers not only from background of Islamic boarding schools, but also from secular educational background. Their capabilities in delivering islamic teachings and organizing majelis taklim lead to create a new elite amongst Muslim women. Meanwhile, in terms of political regulation of $30 \%$ quota for women representation in parliament also supports this condition. Institutionalization of Muslim women elite, in summary, is supported not only by the grass root organization but also by state.

\section{References}

[1] N. Raf, "Dinamika Organisasi Gerakan Sosial Politik Keagamaan Perempuan (Studi 
atas Organisasi Masa Persaudaraan Muslimah di Makassar)," Gadjah Mada, 2019.

[2] W. R. Jati, Politik Kelas Menangah Muslim Indonesia. Jakarta: LP3ES, 2017.

[3] Mattulada, "Bugis-Makassar: Manusia dan Kebudayaannya," Universitas Indonesia, Jakarta, 1974.

[4] C. Pelras, Manusia Bugis. Jakarta: Nalar-Forum Jakarta Paris, 2006.

[5] J. Noorduyn, Islamisasi Makassar. 1972.

[6] O. Burhanuddin, Jajat \& Faturahman, "Menggeser Ruang Domestik ke Publik: Gerakan Perempuan dalam Politik rde Baru," in Tentang Perempuan Islam: Wacana dan Gerakan, Jakarta: Gramedia Utama, 2004, pp. 79-112.

[7] M. Y. Asry, Profiles Beliefs and Religious Movements. Profil Paham dan Gerakan Keagamaan. Jakarta: Puslitbang Kehidupan Keagamaan DEPAG RI, 2009.

[8] K. U. Noer, "Ijtihad Politik Perempuan," in Gender and Politics, S. H. Sastriyani, Ed. Yogyakarta: Tiara Wacana, 2009, pp. 370-377.

[9] J. W. Creswell, Penelitian Kualitatif dan Desain Riset: Memilih Diantara Lima Pendekatan. Yogyakarta: Pustaka Pelajar, 2014.

[10] R. K. Yin, Studi Kasus: Desain dan Metode. Jakarta: RajaGrafindo Persada, 2006.

[11] R. K. Stake, "Studi Kasus," in Handbook of Qualitative Research (Terjemahan), Yogyakarta: Pustaka Pelajar, 2009, pp. 299-315.

[12] B. Suyanto and Sutinah, Metode Penelitian Sosial: Berbagai Alternatif Pendekatan. Jakarta: Prenada Media, 2003.

[13] N. Setiawati, "Majelis Taklim dan Tantangan Pengembangan Dakwah," J. Dakwah Tabligh, vol. 13 No.1, no. Juni, pp. 81-95, 2012.

[14] Mujahidin, "Urgensi Majelis Taklim Sebagai Lembaga Dakwah di Masyarakat," $J$. Alhadharah, vol. 17, no. No.33, pp. 1-12, 2018.

[15] P. . Berger and T. Luckmann, The Social Construction of Reality: A Treatise in the Sociology of Knowledge. Great Britain: Penguin Books, 1991.

[16] G. Riyanto, Peter. Berger: Perspektif Metateori Pemikiran. Jakarta: LP3ES, 2002.

[17] Ginda, "Karakteristik Majelis Taklim sebagai Institusi Pendidikan Non Formal di Manado."

[18] M. Y. Asry, Profil Paham dan Gerakan Keagamaan. Jakarta: Puslitbang Kehidupan Keagamaan DEPAG RI, 2009.

[19] D. Antasari, F. Hasan, L. Nurohmah, and S. W. Eddyono, "The Majlis Taklim and Women: Communializing Private Issue Through Religious Public Space," Yogyakarta, 2010.

[20] N. Raf and et al Lisa, "Profil Majelis Taklim di Kecamatan Tamalanrea," Makassar, 2017.

[21] T. Alawiyah, Strategi Dakwah di ingkungan Majelis Taklim. Bandung: Mizan, 1997.

[22] I. A. Achmad, "Penguatan Keterwakilan Perempuan dalam Kepengurusan Partai," Juristdiction, vol. 1, no. No. 2, pp. 164-181, 2018.

[23] U. Hasanah, "Majelis Taklim Perempuan dan Pergeseran Peran Publik Keagamaan pada Masyarakat Perkotaan,” Universitas Islam Negeri Syarief Hidayatullah, 2016.

[24] J. Lovenduski, "Pendahuluan," in Politik Berparas Perempuan, Yogyakarta: Kanisius, 2008, pp. 13-30.

[25] Jamhari and I. Ropi, Citra Perempuan dalam Islam (Image of Women in Islam). Jakarta: Gramedia Utama, 2003. 